\title{
Unilateral Laterothoracic Exanthem - Asymmetric Periflexural Exanthem of Childhood - a Case Report and Literature Re- view
}

Sonja PRĆIĆ1, 3, ${ }^{*}$, Zorica GAJINOV², ${ }^{3}$, Anica RADULOVIĆ ${ }^{1}$, Milan MATIĆ2, 3 and Aleksandra MATIĆ1, 3

${ }^{1}$ Institute for Child and Youth Health Care of Vojvodina, Pediatric Clinic, Novi Sad, Serbia

${ }^{2}$ Clinic of Dermatovenereology Diseases, Clinical Center of Vojvodina, Novi Sad, Serbia

${ }^{3}$ University of Novi Sad, Faculty of Medicine, Novi Sad, Serbia

*Correspondence: Sonja Prćić, Pediatric Clinic, Institute For Child And Youth Health Care Of Vojvodina, Hajduk Veljkova 10, Novi Sad, Serbia; E-mail: sonja.prcic@mf.uns.ac.rs

UDC 616.511-02-053.2

UDC 616.511-07/-08-053.2

\begin{abstract}
Unilateral laterothoracic exanthem (ULE), or asymmetric periflexural exanthem of childhood (APEC), is an uncommon skin eruption that usually occurs in childhood, with unilateral distribution and self limiting course. The etiology of ULE is unknown, but viral cause is suspected. We report a case of ULE in a 4-year-old girl, that was associated with parvo virus B19 infection, and a brief selected literature review. The patient presented with unilateral maculopapular rash on the left side of the body which was asymptomatic and resolved spontaneously within 5 weeks. The clinical diagnosis of ULE may be precise, ruling out a broad spectrum of differential diagnosis, and prevent unnecessary examinations, whereas the patient is informed about the benign self-limiting nature of ULE. Key words: Exanthema; Child, Preschool; Diagnosis; Parvovirus B19, Human; Signs and Symptoms; Disease Progression
\end{abstract}

\section{Introduction}

Unilateral laterothoracic exanthem (ULE), also known as asymmetric periflexural exanthem of childhood (APEC), is a distinctive selflimiting skin eruption, with unknown etiology, that most commonly occurs in children $(1,2)$.

ULE manifests as a macular or papular rash, that typically develops unilaterally on the skin within or around the axilla, less often in the groin area, and spreads along the same side of the trunk and the corresponding arm or leg (1, 2 - 5). Rarely, the rash progresses bilaterally with an asymmetric predominance (1 - 3, $6)$. The exanthem tends to resolve spontaneosly within $3-6$ weeks $(1-3,5,6)$. Most of the affected patients are otherwise healthy. Histopathological features are rather nonspecific, although skin biopsies were not frequently performed. Perivascular lymphocytic infiltrates tend to cluster around the dermal blood vessels or eccrine ducts, but mild exocytosis and spon- giosis in the epidermis are noted as well $(1,6)$. The cause of ULE is unknown, but viral etiology is suspected $(1,2,4,6-8)$.

\section{Case report}

A four-year-old girl was admitted to our Dermatology Department with a 10-day history of unilateral skin eruptions affecting the left side of her body. The exanthem had begun under her left axilla, and spread centrifugally along the left thoracic wall to the left side of the abdomen and the left arm and leg. The rash was asymptomatic, and there were no constitutional symptoms. Her previous medical hystory was unremarkable. A short course of topical corticosteroid cream (mometasone $0.1 \%$ ) produced no improvement. Dermatological examination revealed numerous coalescing, small erythematous papules on the left side of the trunk (Figure 1), and on the left 


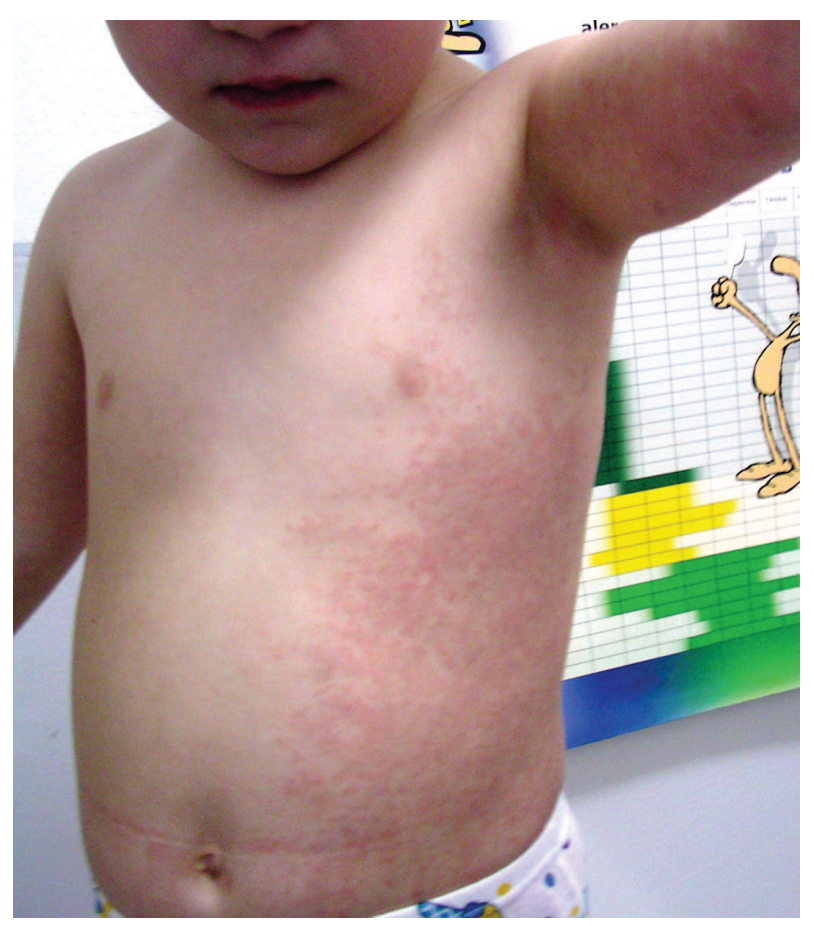

Figure 1. Unilateral laterothoracic exanthem with unilateral distribution ( $10^{\text {th }}$ day)

arm and leg (Figure 2). Clinical diagnosis of ULE was established.

Basic laboratory results (blood count, liver enzymes, C-reactive protein) were normal. Serological tests for Epstein-Barr virus, cytomegalovirus, hepatitis $B$ and $C$ viruses were negative. However, parvovirus B19 serology showed raised IgM and negative IgG titres, indicating a recent infection. Further follow up of parvovirus B19 titer dynamics was not performed. The girl was treated symptomatically with a topical emolient cream, and the lesions resolved in 5 weeks.

\section{Disscusion}

We report a 4-year-old girl with ULE that followed a typical clinical course, associated with parvovirus B19 infection, suggesting that this virus was a possible etiologic factor. ULE is an uncommon disease which mostly affects children between one and five years of age. The eruptions usually start in the axilla, like in our case $(1,2,5,6,8)$. The clinical course of the rash had two phases. The exanthem first began as a centrifugal periflexural spread during the initial 8 days, followed by more widespread skin eruptions (1). Although both sides

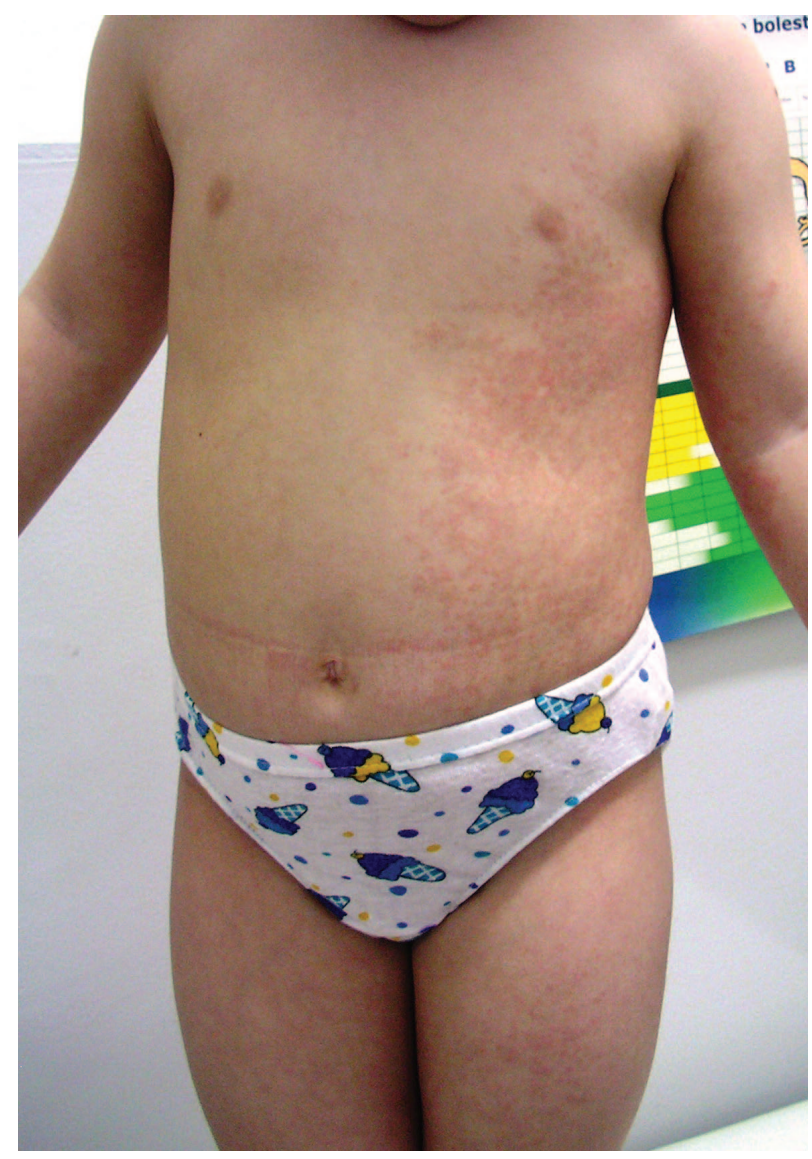

Figure 2. Erythematous papules on the left sides of the chest, abdomen, arm and leg

of the body are affected in $70 \%$ of cases, almost all have a unilateral predominance $(1,2$, $6,8)$. Spontaneous regression of exanthem occurs between the third and sixth week, as in our patient $(1,2,5,6)$. Pruritus and mild local lymphadenopathy is seen in about $50 \%$ patients $(1,2,5,8)$.

The etiology of ULE is unknown, although viral cause has been suggested in a number of cases $(4,6-13)$. Association with adenovirus, parainfluenza virus, parvovirus B19, human herpes virus 6 and 7, and Epstein-Barr virus has been reported in ULE $(4,7,9$ - 13). The virus most commonly associated with ULE was parvovirus B19, like in our case $(10-12)$. ULE is more frequent in the winter and spring (1, 2, 5 8). However, interhuman transmission was not clearly documented (8). In a microbiological case-control study, Coustou et al. were not able to point to a specific virus or bacteria (14).

Several authors recently proposed a term 'superimposed lateralized exanthem of child- 
hood' (SLEC), instead of ULE or APEC. They considered that both terms were innaccurate, as they do not fully match the clinical features of exanthem $(4,15,16)$. The exanthem usually presents in childhood, but there are several reports of adult cases of ULE $(10,12,17$ - 19). The skin eruptions do not always remain unilateral, and they are mostly followed by the appearance of less pronounced bilateral lesions or may affect, at least primarily, the groin area and the legs $(6,8,16)$. Happle hypothesized that strict lateralized involvement can be explained by a postzygotic mutation at an early stage of embryogenesis that may have changed the cutaneous epitopes on one side of the body, causing an altered responsiveness of the skin to various infectious agents (15). In most cases, the subsequent bilateral involvement reflects a less severe reactivity of the contralateral keratinocytes, with a less pronounced polygenic predisposition to develop an inflammatory rash (4). According to this concept, some authors consider SLEC as the most suitable term for this condition $(4,15,16)$.

The proposed mechanism is consistent with the assumption of an infectious etiology of SLEC (4). In our patient, serological findings indicated a recent parvovirus B19 infection, suggesting a causal relation. Many authors have supposed a viral trigger because of the children's age, frequent association of upper respiratory tract or digestive prodromes, serologic findings, spontaneous resolution in a few weeks, and seasonal fluctuations in incidence $(1,6,8,11)$. Duarte et al. considered a relationship to infections with adenovirus, parainfluenza virus 2 or 3 , parvovirus B19, human herpes virus 6 or 7, and Epstein-Barr virus (7).

Differential diagnosis of ULE includes contact dermatitis, nonspecific viral exanthems, atypical pityriasis rosea, drug-related eruptions, miliaria, scarlet fever, GianottiCrosti syndrome, superficial fungal infections and scabies $(2,5,6)$. The diagnosis is clinical, and laboratory investigations and biopsy are generally not required (5).

This uncommon exanthem is self-limiting and usually resolves in three to six weeks with no sequelae $(1-3,5,6,8)$. The treatment is symptomatic including emollients and antihistamines for pruritus.

\section{Conclusion}

The diagnosis of ULE is based on characteristic clinical findings, and patients should be informed about the benign nature and selflimiting course of this disease. Awareness of these conditions is required in order to prevent unnecessary examinations.

\section{Abbreviations}

ULE - Unilateral laterothoracic exanthem APEC - Asymmetric periflexural exanthem of childhood

SLEC - Superimposed lateralized exanthem of childhood

\section{References}

1. Bodemer C, de Prost Y. Unilateral laterothoracic exanthem in children: a new disease? J Am Acad Dermatol. 1992;27(5 Pt 1):693-6.

2. Taieb A, Megraud F, Legrain V, Mortureux P, Maleville J. Asymmetric periflexural exanthem of childhood. J Am Acad Dermatol.1993;29(3):391-3.

3. Brunner MJ, Rubin L, Dunlap F. A new papular erythema of childhood. Arch Dermatol. 1962;85:539-40.

4. Niedermeier A, Pfutzner W, Ruzicka T, Thomas P, Happle R. Superimposed lateralized exanthem of childhoood: report of a case related to adenovirus infection. Clin Exp Dermatol. 2014;39(3):351-3.

5. Gragasin FS, Metelitsa AI. Unilateral laterothoracic exanthem. CMAJ. 2012;184(3):322.

6. McCuaig CC, Russo P, Powell J, Pedneault L, Lebel $P$, Marcoux D. Unilateral laterothoracic exanthem. A clinicopathologic study of forty-eight patients. J Am Acad Dermatol. 1996;34(6):979-84.

7. Duarte AF, Cruz MJ, Baudrier T, Mota A, Azevedo F. Unilateral laterothoracic exanthem and primary Epstein-Barr virus infection: case report. Pediatr Infect Dis J. 2009;28(6):549-50.

8. Coustou D, Leaute-Labreze C, Bioulac-Sage P, Labbe L, Taieb A. Asymmetric periflexural exanthem of childhood: a clinical, pathologic, and epidemio-

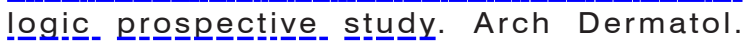
1999;135(7):799-803.

9. Harangi F, Varszegi D, Szucs G. Asymmetric periflexural exanthem of childhood and viral examinations. Pediatr Dermatol. 1995;12(2):112-5.

10. Pauluzzi P, Festini G, Gelmetti C. Asymmetric periflexural exanthem of childhood in an adult patient with parvovirus B19. J Eur Acad Dermatol Venereol. 2001;15(4):372-4.

11. Guimera-Martin-Neda F, Fagundo E, Rodriguez F, Cabrera R, Sánchez R, García M, et al. Asymmetric periflexural exanthem of childhood: report of two 
cases with parvovirus B19. J Eur Acad Dermatol Venereol. 2006;20(4):461-2.

12. Chuh A. Asymmetric periflexural/unilateral laterothoracic exanthem related to parvovirus B19 infection: an adult carrier of beta-globin thalassaemia gene mutation in Hong Kong. Australas J Dermatol. 2016;57(4):e141-3.

13. Scheinfeld N. Unilateral laterothoracic exanthema with coincident evidence of Epstein Barr virus reactivation: exploration of a possible link. Dermatol Online J. 2007;13(3):13.

14. Coustou D, Masquelier B, Lafon ME, Labre`ze C, Roul S, Bioulac-Sage P, et al. Asymmetric periflexural exanthem of childhood: microbiologic casecontrol study. Pediatr Dermatol. 2000;17(3):169-73.
15. Happle R, Nunez Giralda Al. Superimposed lateralized exanthema of childhood: a proposed explanation for an enigmatic disorder. Eur J Dermatol. 2012;22(4):542-4.

16. Drago F, Ciccarese G, Rebora A. Unilateral laterothoracic or asymmetric periflexural exanthem: is time to change the name of the disease? Clin Exp Dermatol. 2015;40(5):570.

17. Corazza M, Virgili A. Asymmetric periflexural exanthem in an adult. Acta Derm Venereol. 1997;77(1):79-80.

18. Bauza A, Redondo P, Fernandez J. Asymmetric peri-

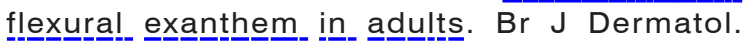
2000;143(1):224-6.

19. Chan PK, To KF, Zawar V, Lee A, Chuh AA. Asymmetric periflexural exanthem in an adult. Clin Exp Dermatol. 2004;29(3):320-1.

\section{Unilateralni laterotorakalni egzantem/asimetrični perifle- ksuralni egzantem dečjeg doba - prikaz slučaja i kratak pregled literature}

\begin{abstract}
Sažetak
Unilateralni laterotorakalni egzantem/asimetrični perifleksuralni egzantem dečjeg doba je egzantem spontano rezolutivnog toka, sa asimetričnom distribucijom promena koji se obično javlja kod male dece. Etiologija unilateralnim laterotorakalnim egzantemom je nepoznata, ali se pretpostavlja da je virusna. Prikazujemo slučaj četvorogodišnje devojčice sa unilateralnim laterotorakalnim egzantemom, udružen sa infekcijom
\end{abstract}

parvo virusom B19, uz kratak pregled izabrane literature. Pacijentkinja je imala asimptomatski unilateralni osip na levoj polovini tela, koji se spontano povukao za pet nedelja. Dijagnoza se postavlja na osnovu karakteristične kliničke slike i toka oboljenja. Pacijente treba informisati o benignoj prirodi i samoograničavajućem toku oboljenja, kako bi se izbegla nepotrebna dodatna ispitivanja.

Ključne reči: Egzantem; Predškolska deca; Dijagnoza; Humani parvovirus B19; Znaci i simptomi; Tok bolesti 